\title{
Influence of Crude Oil Spillage on the $\gamma$-Radiation Status of Water and Soil in Ogba/Egbema/Ndoni Area, Nigeria
}

\author{
Yehuwdah E. Chad-Umoren ${ }^{1} \&$ Efe Ohwekevwo ${ }^{2}$ \\ ${ }^{1}$ Department of Physics, University of Port Harcourt, Rivers State, Nigeria \\ ${ }^{2}$ Department of Physics, Rivers State University of Science and Technology, Port Harcourt, Rivers State, \\ Nigeria \\ Correspondence: Yehuwdah E. Chad-Umoren, Department of Physics, University of Port Harcourt, Rivers State, \\ Nigeria. E-mail: echadumoren@yahoo.com
}

Received: August 29, 2012 Accepted: September 27, 2012 Online Published: July 26, 2013

doi:10.5539/eer.v3n2p45 URL: http://dx.doi.org/10.5539/eer.v3n2p45

\begin{abstract}
Crude oil spillage is one of the variables in the hydrocarbon industry responsible for the impact the industry makes on the ionizing radiation status of its host environment. A study was carried out to investigate the level of impact of oil spillage on the ionizing radiation profile of three communities in the Niger Delta region of Nigeria reputed for its abundant oil wealth. For the purpose, 15 water samples (five from each community) and 15 soil samples (five from each community) were collected and analyzed using the Gamma Scout $\gamma$-spectrometer and $\mathrm{Na}(\mathrm{TI})$ detector. The lowest dose rate for both water and soil was the same $1.14 \pm 0.07 \mathrm{mSv} / \mathrm{yr}(0.014 \pm 0.001$ $\mathrm{mR} / \mathrm{hr})$, while the highest dose rate was also the same for both water and soil $1.58 \pm 0.11 \mathrm{mSv} / \mathrm{yr}(0.019 \pm 0.001$ $\mathrm{mR} / \mathrm{hr}$ ). However, the minimum dose rate, maximum dose rate and mean dose rate computed for water differed from those computed for soil. The study showed that all computed radiation parameters for both water and soil, including the minimum dose rates measured for the three communities, exceeded international regulatory standards for the general populace indicating that oil spill had resulted in the elevation of the radiation levels of the affected communities and that appropriate steps need to be taken to protect those living in the study area from radiation hazards.
\end{abstract}

Keywords: Radiation dose, hydrocarbon industry, radiation exposure, water samples, soil samples, oil spillage, Niger Delta region

\section{Introduction}

The Niger Delta region of Nigeria is recognized as critical to global oil security and indispensable to the nation's economic wellbeing. But the Niger delta has also become a victim of its hydrocarbon wealth. The exploitation of its abundant hydrocarbon resources has led to the despoliation and pollution of its environment. Inability to properly harness the abundant gas wealth of the region has led to the environmentally destructive practice of gas flaring which releases harmful gaseous pollutants into the atmosphere. A study of the ambient air pollutants in the region indicates that existing Federal environmental standards were grossly exceeded for particulate matter, oxides of carbon, nitrogen and sulphur (Oluwole et al., 1996).

Activities of the hydrocarbon industry also result in the elevation of the ionizing radiation levels of its host locations in the region. In a study of the external environmental radiation status of some industrial locations in Port Harcourt, which included oil and gas facilities, an average value of $0.014 \mathrm{mR} \mathrm{h}^{-1}$ was reported for the background, showing an elevation from the standard background radiation level of $0.013 \mathrm{mR} \mathrm{h}^{-1}$ (Avwiri \& Ebeniro, 1998). Arogunjo et al. (2004) studied the impact of the oil and gas industry on the natural radioactivity distribution in the region and showed that the mean activity concentration of ${ }^{40} \mathrm{~K},{ }^{238} \mathrm{U}$ and ${ }^{234} \mathrm{Th}$ were $34.8 \pm 2.4,16.2 \pm 3.7$ and $24.4 \pm 4.7 \mathrm{Bqkg}^{-1}$, respectively. It was further observed that areas with oil extraction activities had higher activity concentrations than those without any known oil extraction activity in the region. Stanislav and Elena (1998) studied the environmental impact of offshore oil and gas facilities and showed that produced water from oil and gas production contained naturally occurring radioactive elements (Uranium and Thorium) and their daughter products $\left({ }^{226} \mathrm{Ra}\right.$ and $\left.{ }^{228} \mathrm{Ra}\right)$. 
Ononugbo et al. (2011) carried out a study of the terrestrial radioactivity in the industrial areas of Ogba/Egbema/Ndoni Local Government Area (ONELGA) of Rivers state. The industrial areas and their host communities were divided into six (6) zones, each having an oil and gas facility. An in situ measurement was done using two well calibrated nuclear radiation meters, a digilert-100 and a digilert-50 and a geographical positioning system (GPS). Ten readings were taken in each of the six zones and the host community at randomly selected sites, making a total of 60 sampling points. The mean site radiation levels that were obtained ranged from $0.014 \pm 0.001 \mathrm{mRh}^{-1}\left(1.183 \pm 0.060 \mathrm{mSvyr}^{-1}\right)$ to $0.018 \pm 0.002 \mathrm{mRh}^{-1}\left(1.183 \pm 0.085 \mathrm{mSvyr}^{-1}\right)$, while the mean community radiation levels ranged from $0.014 \pm 0.001 \mathrm{mRh}^{-1}\left(1.183 \pm 0.06 \mathrm{mSvyr}^{-1)}\right.$ to $0.017 \pm 0.001$ $\mathrm{mRh}^{-1}\left(1.435 \pm 0.072 \mathrm{mSvyr}^{-1}\right)$. The equivalent dose had an average range of $1.056 \mathrm{mSvyr}^{-1}$ to $2.871 \mathrm{mSvyr}^{-1}$, which is much lower than the International Commission on Radiological Protection recommended 20 mSvyr $^{-1}$ dose limit for radiological workers, but above the permissible level of $1 \mathrm{mSv} / \mathrm{yr}$ recommended for the general public (ICRP, 1990). Further analysis showed that 43 sites or $72 \%$ of the sampling sites exceeded the normal background level of $0.013 \mathrm{mRh}^{-1}$ indicating a certain level of radiation risk for the communities hosting the facilities.

Ebong and Alagoa(1992) have shown that the nature of input raw materials, effluents from the production process and the output production determine the effect of an industrial operation on the radiation levels of its host environment. In the case of the hydrocarbon industry there are a number of variables associated with the industry that contribute to the impact the industry makes on the ionizing radiation profile of its areas of operation. These include the use of radiation generators, sealed and unsealed sources of radioactive materials, naturally occurring radioactive materials (NORMs) originating from reservoir rocks, scales, sludge, oil spillage and gas flaring (Chad-Umoren, 2012; Meindinyo \& Agbalagba, 2012; OGP, 2008; Sigalo \& Briggs-Kamara, 2004).

However, in some locations, particular variables may be more critical than others. This present study investigates the impact of crude oil spillage as an isolated variable and as the only industry variable affecting the radiation patterns of three communities - Ebegoro, Ebocha and Obrikom in the Ogba/Egbema/Ndoni Local Government Area (ONELGA) in Nigeria's Niger Delta state of Rivers where the operations of a multinational oil firm had led to the release of enormous quantities of crude oil into the environment.

Studies on the impact of the oil and gas industry on the ionizing radiation profile of the Niger Delta region had tended to focus on the contribution of oil and gas facilities (Chad-Umoren \& Briggs-Kamara, 2010; Chukwuocha \& Enyinna, 2009; Avwiri et al., 2007). Furthermore, there has been only one previous study in ONELGA (Ononugbo et al., 2011) and that had followed the traditional mode of focusing mainly on the impact of facilities such as gas processing plants, flow stations, natural gas compressor stations. There is therefore the need to properly document the effect incessant oil spillage has had on the level of background ionizing radiation of the area. This work provides base-line data for future studies.

Oil spillage is often an unintended release of crude oil into the environment as a result of human activity. Such accidents may involve a refinery, an oil storage facility, barges, oil tankers or oil pipelines. Oil spillage has been described as a major source of water pollution in the Niger Delta region and the increase in its frequency has been attributed to the growth of the industry and the prevalence of ageing oil pipelines. A total of 10,260 oil spills is estimated to have occurred in the region between 1976 and 2007 resulting in the loss of about seven million barrels of oil. Of this quantity, $6 \%$ was spilled on land, $25 \%$ in swamps and $69 \%$ in offshore environment (NREP, 2008).

Crude oil is both toxic due to its toxic chemical content and radioactive due to its radionuclide content, specifically the presence of Uranium and Thorium. These radiouclides and members of their decay chains are found in the earth's crust and therefore become incorporated into the crude oil during the process of oil drilling and production (Chad-Umoren, 2012; OGP, 2008). The prevalence of these radionuclides is depth-dependent so that the level of radioactivity of given crude is determined by the depth of the well that is its source. The deeper the oil well, the more radioactive the crude oil. Consequently, depending on the radioactive nature of the crude, spillage can lead to harmful elevation of the ionizing radiation profile of the environment.

\section{Study Area}

Ebegoro, Ebocha and Obrikom, the three communities chosen for this study are communities in the Ogba/Egbema/Ndoni Local Government Area (ONELGA) in Nigeria's Niger Delta state of Rivers. ONELGA is located within latitudes $5^{\circ} 23^{\prime} \mathrm{N}$ and $5^{\circ} 26^{\prime} \mathrm{N}$ and longitudes $6^{\circ} 33^{\prime} \mathrm{E}$ and $6^{\circ} 42^{\prime}$ North West and has a topography of flat plains in a network of rivers - the Niger, Sombreiro (Nkissa), Orashi and their tributaries along with a series of creeks. It is one of the onshore oil producing areas of Rivers state and has one of the highest oil and gas production onshore of the Niger-Delta with over 900 oil wells, more than thirteen active oil fields and playing 
host to a number of multinational companies (Abali, 2009). The area has a labyrinth of pipelines carrying oil or gas to flow stations from the different oil wells (UNDP, 2006). Oil and gas activities started in ONELGA in 1964 with actual production commencing in 1966. Since then, production activities have been continuous with increase in the number of drilled oil wells. Gas flaring and oil spillage due to rupture of pipes have been the major sources of environmental pollution in the area.

\section{Sample Collection, Preparation and Analyses}

The study involved two sets of evaluations - on-site evaluation at the three communities and laboratory analyses. The RadEye Gamma survey meter with a non linear pulse to dose rate conversion capability and a geographical positioning system (GPS) were used for the on-site radiation monitoring. Measurement technique adopted followed the usual procedure for in situ measurements (Chad-Umoren et al., 2006; Avwiri et al., 2009).

The laboratory study was carried out using water and soil samples collected from spill sites in the three selected communities. In each community, five sampling locations were randomly chosen, but to as much as possible cover the community. Fifteen soil samples (five from each of the three communities) and fifteen water samples (five also from each of the three communities) were collected from the delineated spill sites. About $2 \mathrm{~kg}$ of soil samples were collected from the spill sites and stored in black plastic bags directly after collection to prevent contamination from atmospheric humidity. The volume of water samples collected from the spill sites was about one litre and also stored in a manner that preserved sample integrity.

The samples were later analysed at the laboratory of the Centre for Energy Research and Development, Obafemi Awolowo University, Ile Ife, Nigeria. The soil samples were first air dried, sieved through $2 \mathrm{~mm}$ and stored in plastic bags for a period of 28 days to allow them attain secular equilibrium before analysis.

The following conversion factors were used:

$$
\begin{aligned}
& 1 \mu \mathrm{Sv} / \mathrm{hr}=365 \times 24 \times 10^{-3} \mathrm{mSv} / \mathrm{yr} \\
& 1 \mathrm{mSv} / \mathrm{yr}=0.0119 \mathrm{mR} / \mathrm{hr}
\end{aligned}
$$

\section{Results and Discussions}

\begin{tabular}{|c|c|c|c|c|c|c|}
\hline Community & $\begin{array}{l}\text { Sampling } \\
\text { Site }\end{array}$ & Geographical & Field Location & $\begin{array}{l}\text { Dose Rate Laboratory } \\
\text { result }(\mu \mathrm{Sv} / \mathrm{hr})\end{array}$ & $\begin{array}{l}\text { Equivalent } \\
\text { Dose }(\mathrm{mSv} / \mathrm{yr})\end{array}$ & $\begin{array}{l}\text { Radiation } \\
\text { Level }(\mathrm{mR} / \mathrm{hr})\end{array}$ \\
\hline \multirow{5}{*}{ Ebegoro } & 1 & N05 $23^{\prime} 04.4^{\prime \prime}$ & E006 $399^{\prime} 27^{\prime \prime}$ & $0.18 \pm 0.018$ & $1.58 \pm 0.16$ & $0.019 \pm 0.002$ \\
\hline & 2 & N05 $23^{\prime} 9^{\prime \prime}$ & E006 $3949 "$ & $0.18 \pm 0.018$ & $1.58 \pm 0.16$ & $0.019 \pm 0.002$ \\
\hline & 3 & N05 2349 " & E006 $399^{\circ} 35^{\prime \prime}$ & $0.16 \pm 0.016$ & $1.40 \pm 0.14$ & $0.017 \pm 0.002$ \\
\hline & 4 & $\mathrm{~N} 05^{0} 2330.6^{\prime \prime}$ & E006 $399^{\prime} 36^{\prime \prime}$ & $0.16 \pm 0.011$ & $1.40 \pm 0.10$ & $0.017 \pm 0.001$ \\
\hline & 5 & $\mathrm{~N} 05^{\circ} 23^{\prime} 0^{\prime \prime}$ & E006 40 ' $37.5^{\prime \prime}$ & $0.17 \pm 0.017$ & $1.49 \pm 0.15$ & $0.018 \pm 0.002$ \\
\hline \multirow{5}{*}{ Ebocha } & 1 & N05 $2721.8^{\prime \prime}$ & E006 $41^{\prime} 33.3^{\prime \prime}$ & $0.16 \pm 0.014$ & $1.40 \pm 0.12$ & $0.017 \pm 0.001$ \\
\hline & 2 & $\mathrm{~N} 05^{\circ} 27^{\prime} 22.2^{\prime \prime}$ & E006 $41^{\prime} 34^{\prime \prime}$ & $0.16 \pm 0.013$ & $1.40 \pm 0.11$ & $0.017 \pm 0.001$ \\
\hline & 3 & N05 $26^{\prime} 1^{\prime \prime}$ & $\mathrm{E} 006^{0} 4023.8^{\prime \prime}$ & $0.15 \pm 0.015$ & $1.31 \pm 0.13$ & $0.016 \pm 0.002$ \\
\hline & 4 & N05 $27^{\circ} 2^{\prime \prime}$ & E $006^{0} 40^{\prime} 58^{\prime \prime}$ & $0.14 \pm 0.014$ & $1.23 \pm 0.12$ & $0.015 \pm 0.001$ \\
\hline & 5 & $\mathrm{~N} 05^{\circ} 2321.5^{\prime \prime}$ & $\mathrm{E} 006^{0} 45^{\prime} 35.5^{\prime \prime}$ & $0.16 \pm 0.013$ & $1.40 \pm 0.11$ & $0.017 \pm 0.001$ \\
\hline \multirow{5}{*}{ Obrikom } & 1 & $\mathrm{~N} 05^{0} 2330^{\prime \prime}$ & E006 $3923^{\prime \prime}$ & $0.15 \pm 0.011$ & $1.31 \pm 0.10$ & $0.016 \pm 0.001$ \\
\hline & 2 & N05 $2330^{\circ}$ & E006 $4033^{\prime \prime}$ & $0.14 \pm 0.014$ & $1.23 \pm 0.12$ & $0.015 \pm 0.001$ \\
\hline & 3 & $\mathrm{~N} 05^{0} 28^{\prime} 23$ & $\mathrm{E} 006^{0} 42^{\prime} 53^{\prime \prime}$ & $0.13 \pm 0.013$ & $1.14 \pm 0.11$ & $0.014 \pm 0.001$ \\
\hline & 4 & $\mathrm{~N} 05^{0} 28^{\prime} 40^{\prime \prime}$ & E006 $35^{\circ} 6^{\prime \prime}$ & $0.14 \pm 0.014$ & $1.23 \pm 0.12$ & $0.015 \pm 0.001$ \\
\hline & 5 & $\mathrm{~N} 05^{0} 2335^{\prime \prime}$ & E006 $27^{\circ} 40^{\prime \prime}$ & $0.17 \pm 0.014$ & $1.49 \pm 0.12$ & $0.018 \pm 0.001$ \\
\hline
\end{tabular}

Table 1. Dose rate and geographical location for water samples

Table1 shows the radiation profile of the water samples and the GPS co-ordinates. These results show that the highest radiation dose was obtained at Ebegoro, while the lowest was recorded at Obrikom. Table 2 shows the maximum dose rate, minimum dose rate and mean dose rate for the water from the three communities and the ICRP maximum exposure level for the general public. A consideration of the mean radiation dose values show that the highest value was obtained at Ebegoro with a value of $1.49 \pm 0.14 \mathrm{mSv} / \mathrm{yr}(0.018 \pm 0.002 \mathrm{mR} / \mathrm{hr})$ while the lowest was recorded at Obrikom with a value of $1.28 \pm 0.11 \mathrm{mSv} / \mathrm{yr}(0.016 \pm 0.001 \mathrm{mR} / \mathrm{hr})$. The radiation contamination of the water from the spill sites is nearly homogeneous across the three communities as the 
difference between the largest value and the least is only $0.35 \mathrm{mSv} / \mathrm{yr}$ or $22 \%$. The implication will be that the spillage was uniformly distributed in the community water sources.

Also, a comparison of the maximum dose rate, minimum dose rate and mean dose rate for the water from the three communities with the ICRP reference level shows that these quantities have values that are higher than the ICRP standard. As shown in Figures 1 and 2, the radiation profile is such that even the lowest radiation levels in each of the spill site exceed the ICRP reference level. The minimum exposure level in Obrikom is $14 \%$ above the ICRP level, while the maximum exposure level is $49 \%$ higher. In Ebocha the minimum dose rate is $23 \%$ above the ICRP standard and the maximum 40\%. The minimum exposure level in Ebegoro is $40 \%$ above the ICRP value and the maximum exposure level $58 \%$.

Table 2. Maximum, minimum, mean and icrp radiation dose and exposure rates (water samples)

\begin{tabular}{lllcccccc}
\hline \multirow{2}{*}{ Spill Site } & \multicolumn{2}{c}{ Maximum } & \multicolumn{2}{c}{ Minimum } & \multicolumn{2}{c}{ Mean } & \multicolumn{2}{c}{ ICRP } \\
\cline { 2 - 10 } & $\mathrm{mSv} / \mathrm{yr}$ & $\mathrm{mR} / \mathrm{hr}$ & $\mathrm{mSv} / \mathrm{yr}$ & $\mathrm{mR} / \mathrm{hr}$ & $\mathrm{mSv} / \mathrm{yr}$ & $\mathrm{mR} / \mathrm{hr}$ & $\mathrm{mSv} / \mathrm{yr}$ & $\mathrm{mR} / \mathrm{hr}$ \\
\hline Ebegoro & $1.58 \pm 0.16$ & $0.019 \pm 0.002$ & $1.40 \pm 0.10$ & $0.017 \pm 0.001$ & $1.49 \pm 0.14$ & $0.018 \pm 0.002$ & 1.000 & 0.013 \\
Ebocha & $1.40 \pm 0.12$ & $0.017 \pm 0.001$ & $1.23 \pm 0.12$ & $0.015 \pm 0.001$ & $1.35 \pm 0.12$ & $0.016 \pm 0.001$ & 1.000 & 0.013 \\
Obrikom & $1.49 \pm 0.12$ & $0.018 \pm 0.001$ & $1.14 \pm 0.11$ & $0.014 \pm 0.001$ & $1.28 \pm 0.11$ & $0.016 \pm 0.001$ & 1.000 & 0.013 \\
\hline
\end{tabular}

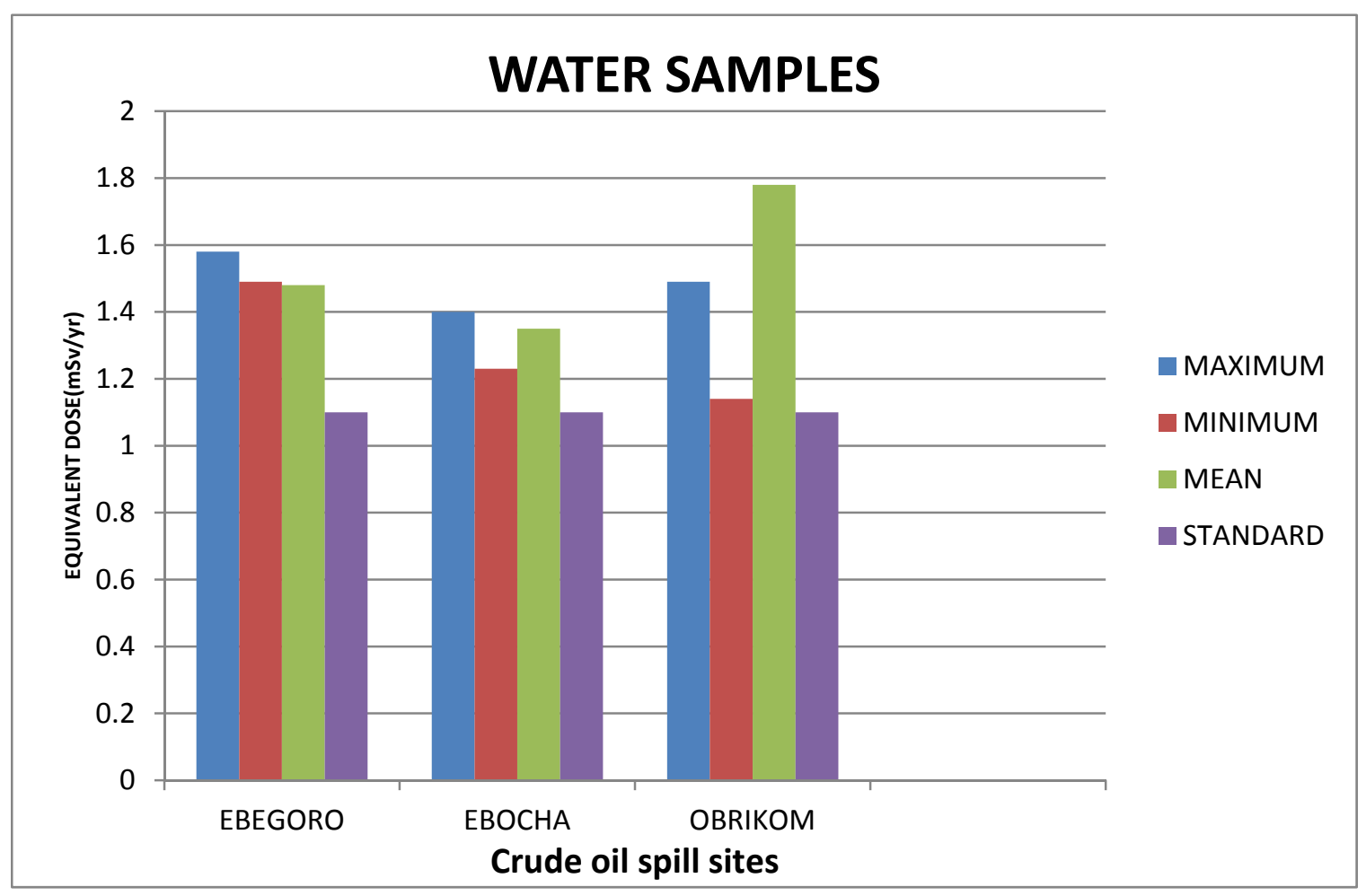

Figure 1. Comparison of maximum, minimum, mean and permissible (ICRP) radiation dose rate (water) 


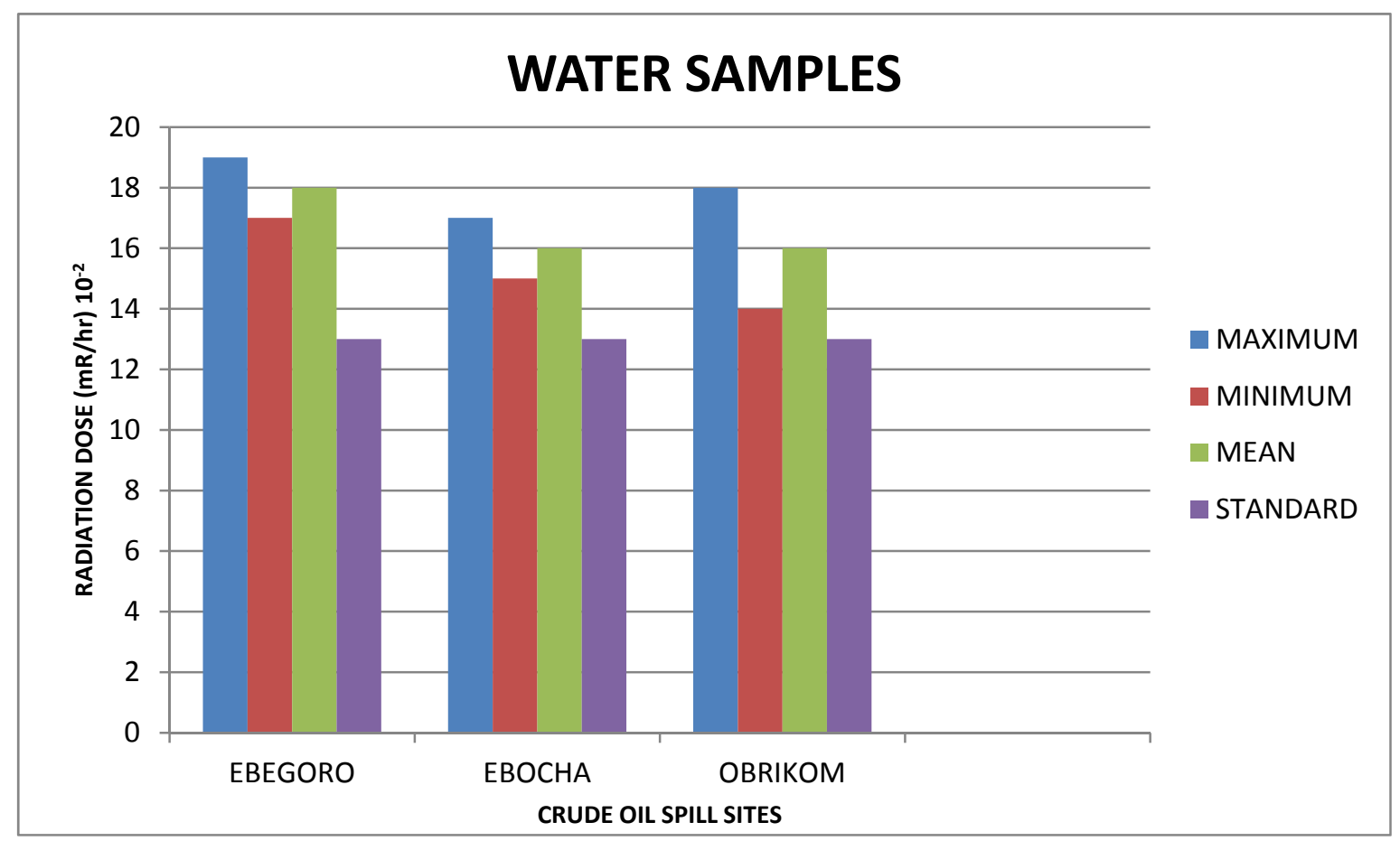

Figure 2. Comparison of maximum, minimum, mean and permissible (ICRP) radiation exposure rates for water

Table 3. Dose rate and geographical location for soil samples

\begin{tabular}{|c|c|c|c|c|c|}
\hline Community & Site & Geographical Field Location & $\begin{array}{l}\text { Dose Rate } \\
\text { Laboratory } \\
\text { result }(\mu \mathrm{Sv} / \mathrm{hr})\end{array}$ & $\begin{array}{l}\text { Equivalent } \\
\text { Dose }(\mathrm{mSv} / \mathrm{yr})\end{array}$ & $\begin{array}{l}\text { Radiation } \\
\text { Level(mR/h) }\end{array}$ \\
\hline \multirow{5}{*}{ Ebegoro } & 1 & $\mathrm{~N}^{0} 5^{0} 23^{\prime} 04.4^{\prime \prime} \mathrm{E} 006^{0} 39^{\prime} 27^{\prime \prime}$ & $0.17 \pm 0.017$ & $1.49 \pm 0.15$ & $0.018 \pm 0.002$ \\
\hline & 2 & N05 $23^{\prime} 9^{\prime \prime} \quad$ E006 $399^{\prime} 49^{\prime \prime}$ & $0.18 \pm 0.013$ & $1.58 \pm 0.11$ & $0.019 \pm 0.001$ \\
\hline & 3 & $\mathrm{~N}^{0} 5^{0} 23^{\prime} 49^{\prime \prime} \quad$ E006 $39^{\circ} 35^{\prime}$, & $0.17 \pm 0.017$ & $1.49 \pm 0.15$ & $0.018 \pm 0.002$ \\
\hline & 4 & N05 23 '30.6"E006 39 '36", & $0.16 \pm 0.014$ & $1.40 \pm 0.12$ & $0.017 \pm 0.001$ \\
\hline & 5 & $\mathrm{~N}^{0} 5^{0} 23^{\prime} 0^{\prime \prime} \quad \mathrm{E}_{006}{ }^{0} 40^{\prime} 37.5^{\prime \prime}$ & $0.18 \pm 0.018$ & $1.58 \pm 0.16$ & $0.019 \pm 0.002$ \\
\hline \multirow{5}{*}{ Ebocha } & 1 & N05 $2721.8^{\prime \prime} \quad$ E006 $4133.3^{\prime \prime}$ & $0.14 \pm 0.014$ & $1.23 \pm 0.12$ & $0.015 \pm 0.001$ \\
\hline & 2 & N05 $27^{\prime} 22.2^{\prime \prime}$ E006 $41^{\prime} 34^{\prime \prime}$ & $0.14 \pm 0.014$ & $1.23 \pm 0.12$ & $0.015 \pm 0.001$ \\
\hline & 3 & $\mathrm{~N}^{0} 5^{0} 26^{\prime} 1^{\prime \prime} \quad \mathrm{E} 006^{0} 40^{\prime} 23.8^{\prime \prime}$ & $0.16 \pm 0.016$ & $1.40 \pm 0.14$ & $0.017 \pm 0.002$ \\
\hline & 4 & N05 $27^{\circ} 2^{\prime \prime} \quad$ E006 $400^{\prime} 58^{\prime \prime}$ & $0.17 \pm 0.017$ & $1.49 \pm 0.15$ & $0.018 \pm 0.002$ \\
\hline & 5 & N05 23 '21.5" E006 $45^{\prime} 35.5^{\prime \prime}$ & $0.16 \pm 0.016$ & $1.40 \pm 0.14$ & $0.017 \pm 0.002$ \\
\hline \multirow{5}{*}{ Obrikom } & 1 & N05 $2330^{\prime \prime} \quad \mathrm{E}^{\circ} 06^{0} 39^{\prime} 23^{\prime \prime}$ & $0.16 \pm 0.016$ & $1.40 \pm 0.14$ & $0.017 \pm 0.002$ \\
\hline & 2 & $\mathrm{~N}^{0} 5^{0} 23^{\prime} 30^{\prime \prime} \quad \mathrm{E} 006^{0} 40^{\prime} 33^{\prime \prime}$ & $0.17 \pm 0.014$ & $1.49 \pm 0.12$ & $0.018 \pm 0.001$ \\
\hline & 3 & N05 $28^{\prime} 23$ E006 $42^{\prime} 53^{\prime \prime}$ & $0.17 \pm 0.015$ & $1.49 \pm 0.13$ & $0.018 \pm 0.002$ \\
\hline & 4 & N05 $28^{\prime} 40^{\prime \prime E} 006^{0} 35^{\prime} 6^{\prime \prime}$ & $0.15 \pm 0.012$ & $1.31 \pm 0.11$ & $0.016 \pm 0.001$ \\
\hline & 5 & N05 $2335^{\circ}$ "E $006^{0} 27^{\prime} 40^{\prime \prime}$ & $0.13 \pm 0.008$ & $1.14 \pm 0.07$ & $0.014 \pm 0.001$ \\
\hline
\end{tabular}

Table 4. Minimum, maximum, mean and icrp radiation dose and exposure rates (soil samples)

\begin{tabular}{lllcccccc}
\hline \multirow{2}{*}{ Community } & \multicolumn{2}{c}{ Maximum } & \multicolumn{2}{c}{ Minimum } & \multicolumn{2}{c}{ Mean } & \multicolumn{2}{c}{$\mathrm{ICRP}$} \\
\cline { 2 - 9 } & $\mathrm{mSv} / \mathrm{yr}$ & $\mathrm{mR} / \mathrm{hr}$ & $\mathrm{mSv} / \mathrm{yr}$ & $\mathrm{mR} / \mathrm{hr}$ & $\mathrm{mSv} / \mathrm{yr}$ & $\mathrm{mR} / \mathrm{hr}$ & $\mathrm{mSv} / \mathrm{yr}$ & $\mathrm{mR} / \mathrm{hr}$ \\
\hline EBEGORO & $1.58 \pm 0.11$ & $0.019 \pm 0.001$ & $1.40 \pm 0.12$ & $0.017 \pm 0.001$ & $1.51 \pm 0.14$ & $0.018 \pm 0.002$ & 1.00 & 0.013 \\
EBOCHA & $1.49 \pm 0.15$ & $0.018 \pm 0.002$ & $1.23 \pm 0.12$ & $0.015 \pm 0.001$ & $1.35 \pm 0.13$ & $0.016 \pm 0.002$ & 1.00 & 0.013 \\
OBRIKOM & $1.49 \pm 0.12$ & $0.018 \pm 0.001$ & $1.14 \pm 0.07$ & $0.014 \pm 0.001$ & $1.37 \pm 0.11$ & $0.017 \pm 0.001$ & 1.00 & 0.013 \\
\hline
\end{tabular}




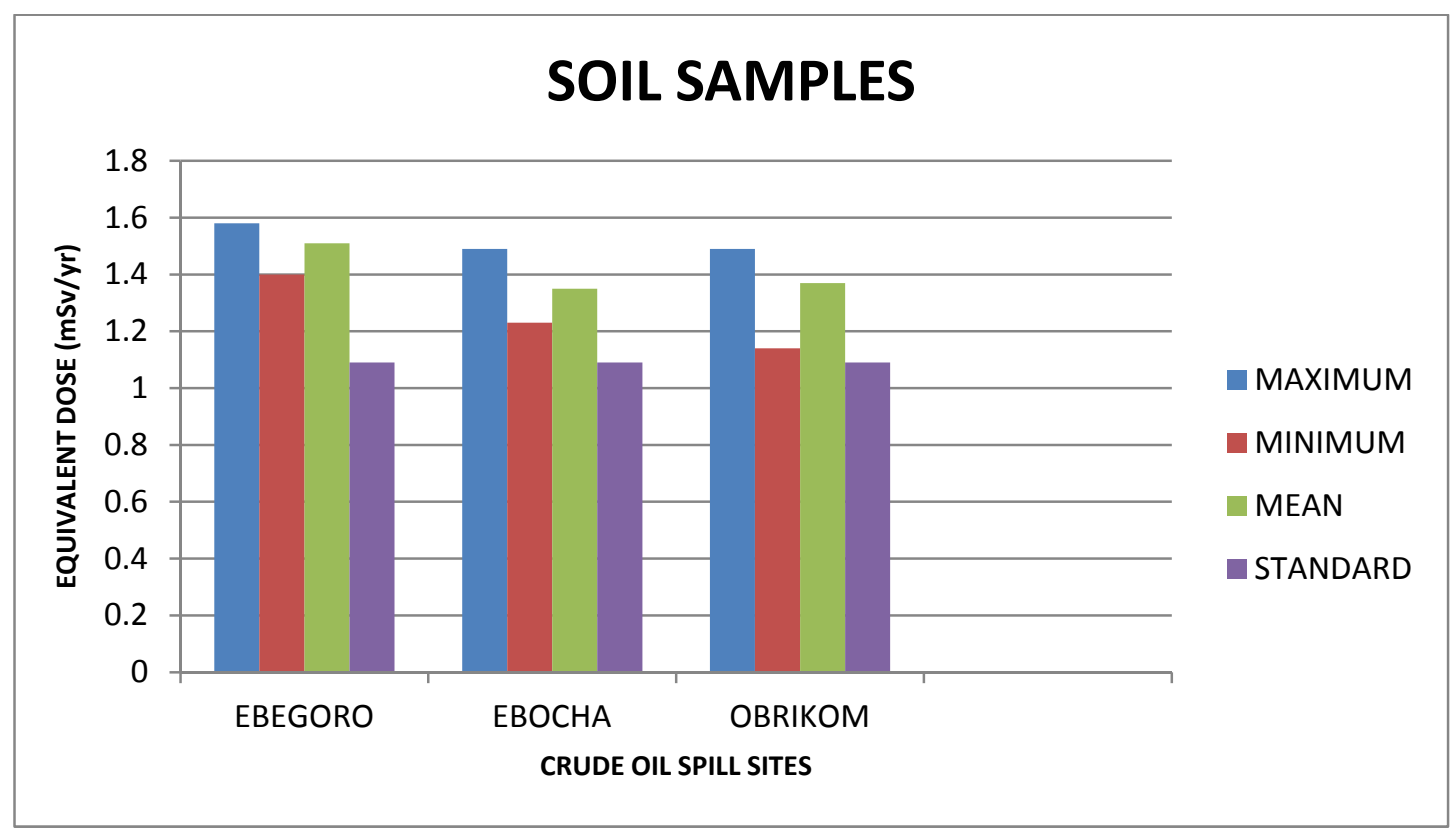

Figure 3. Comparison of minimum, maximum, mean and permissible radiation dose rate

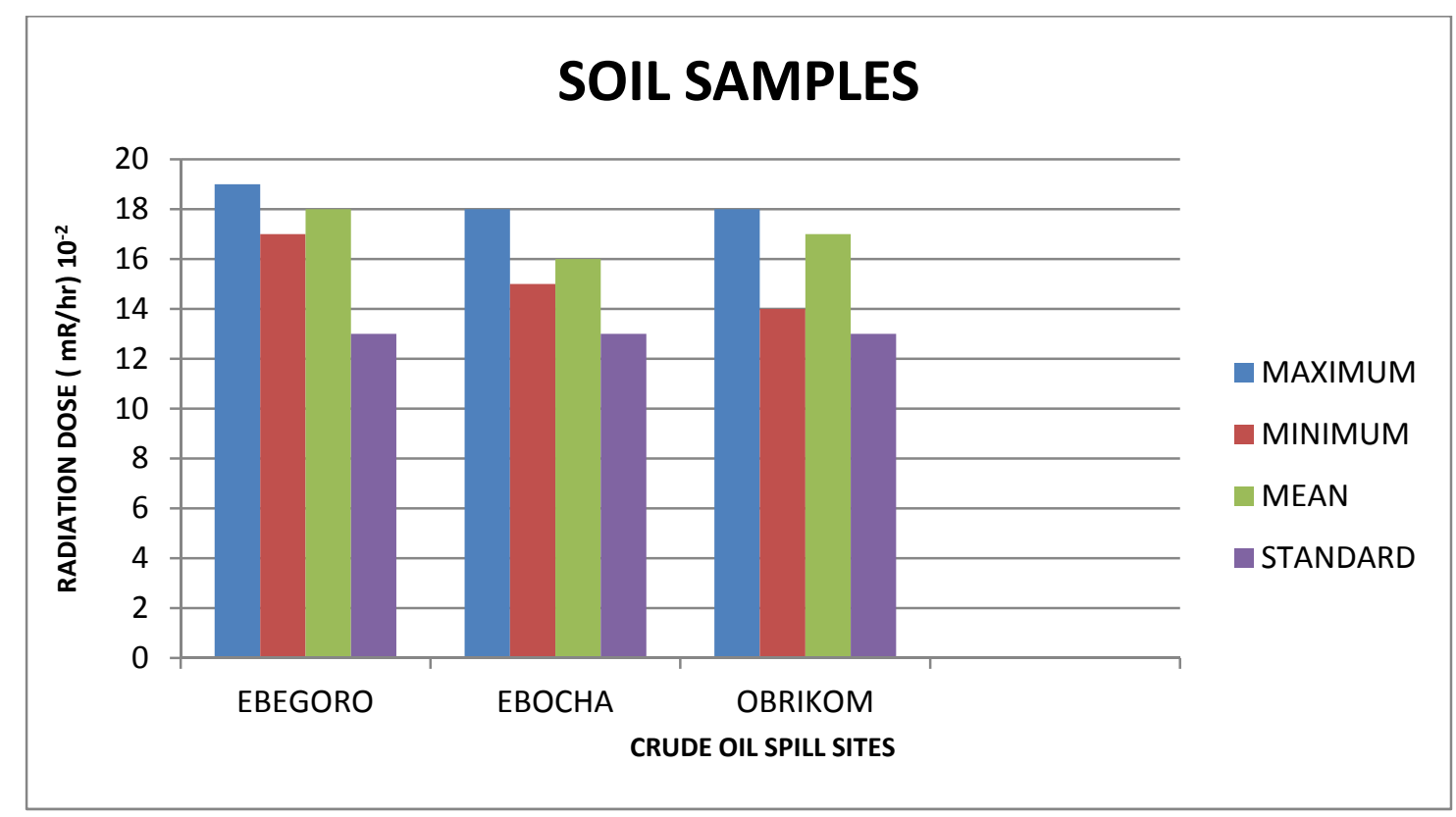

Figure 4. Comparison of radiation dose rate of maximum, minimum, mean and permissible radiation exposure rate

The radiation profile of the soil samples (Table 3) shows the following ranges for the various communities: for Ebegoro community the radiation level ranges from $1.40 \pm 0.12 \mathrm{mSv} / \mathrm{yr}(0.017 \pm 0.001 \mathrm{mR} / \mathrm{hr})$ to $1.58 \pm 0.11 \mathrm{mSv} / \mathrm{yr}$ $(0.019 \pm 0.001 \mathrm{mR} / \mathrm{hr})$; while it goes from $1.23 \pm 0.12 \mathrm{mSv} / \mathrm{yr}(0.015 \pm 0.001 \mathrm{mR} / \mathrm{hr})$ to $1.49 \pm 0.15 \mathrm{mSv} / \mathrm{yr}$ $(0.018 \pm 0.002 \mathrm{mR} / \mathrm{hr})$ at Ebocha. For Obrikom, the range is from $1.14 \pm 0.07 \mathrm{mSv} / \mathrm{yr}(0.014 \pm 0.001 \mathrm{mR} / \mathrm{hr})$ to $1.49 \pm 0.12 \mathrm{mSv} / \mathrm{yr}(0.018 \pm 0.001 \mathrm{mR} / \mathrm{hr})$. The highest value was recorded at Ebegoro, while the least was obtained from Obrikom.

Table 4 shows the maximum dose rate, minimum dose rate, mean dose rate for the soil from the three communities and the ICRP permissible maximum exposure level for the general public. The highest mean radiation value is $1.51 \pm 0.14 \mathrm{mSv} / \mathrm{yr}(0.018 \pm 0.002 \mathrm{mR} / \mathrm{hr})$, obtained at Ebegoro; while the lowest is $1.35 \pm 0.13$ $\mathrm{mSv} / \mathrm{yr}(0.016 \pm 0.002 \mathrm{mR} / \mathrm{hr})$, recorded at Ebocha. The radiation contamination of the soil from the spill sites is 
near evenly spread over the three communities as the difference between the largest value and the least is only $0.16 \mathrm{mSv} / \mathrm{yr}$ or $10.6 \%$.

Figures 3 and 4 show that as in the case of the water samples, the minimum dose rate, maximum dose rate and mean dose rate computed for soil samples from the various communities exceed the ICRP reference limit for the general public. The minimum exposure level in Obrikom is $14 \%$ higher than the ICRP permissible level, while the maximum exposure level is $49 \%$. In Ebocha, the minimum exposure level is $23 \%$ above the ICRP level and the maximum exposure 49\%; while in Ebegoro the minimum exposure level is $40 \%$ above the ICRP standard and the maximum exposure level is $58 \%$ higher.

Comparing the radiation profile of both water and soil it is seen that the lowest radiation dose rate for both is the same $(1.14 \pm 0.014 \mathrm{mSv} / \mathrm{yr}(0.014 \pm 0.001))$. This result was obtained in the same community, Obrikom. Similarly, it is also seen that the highest radiation dose rate for water is the same with that for soil $(1.58 \pm 0.16 \mathrm{mSv} / \mathrm{yr}$ $(0.019 \pm 0.002 \mathrm{mR} / \mathrm{hr}))$. This result was also recorded in one community, Ebegoro.

Furthermore, the results show that the impact of the oil spillage on the radiation status of the three communities is more pronounced in Ebegoro than in Obrikom.

A study of the impact of oil spillage in parts of Ughelli another Niger Delta community, showed that radiation levels within the areas affected by the spillage and the host communities were $55 \%$ and $33.3 \%$, respectively above the normal background level of $0.013 \mathrm{mR} / \mathrm{hr}$ indicating elevations attributable to the spillage (Agalagba \& Meindinyo, 2010). Other studies in the region have shown that the hydrocarbon industry is contributing to an increasingly worrisome ionizing radiation climate in the region (Arogunjo et al., 2004; Chad-Umoren, 2012; Ononugbo et al., 2011; Sigalo \& Briggs-Kamara, 2004).

\section{Conclusion and Recommendation}

(1) A comparison of the radiation profiles of the water with that of the soil indicates that the impact of the spillage on the radiation levels is generally the same for both as the measured values are basically the same for both.

(2) Although the community least affected by the impact of the spillage on the radiation profile is the Obrikom community as it has the lowest radiation levels for both water and soil, however the observed radiation values for this community exceeds the ICRP permissible level for the general public.

(3) The results of the present study are significantly higher than those of earlier studies carried out in parts of the Niger Delta at locations that had not experienced oil spillage (Chad-Umoren \& Obinoma, 2007; Briggs-Kamara et al., 2009; Chad-Umoren et al., 2006), indicating that oil spillage has resulted in the elevation of the radiation profile of the study area.

(4) Regular maintenance of oil pipelines and prompt replacement of old and obsolete ones should be carried out. Lack of regular maintenance of storage tanks and oil pipelines has been identified as a major cause of oil spills in Nigeria.

(5) It may not be possible to completely eliminate oil spillage in the Niger Delta region since it is connected to the beneficial exploitation of the hydrocarbon resources of the region and it is not economically prudent to stop exploiting the region's abundant natural endowments; however, the indigenous peoples of the region and other residents should be provided with facilities that will enable them receive prompt medical help, especially with respect to those ailments that are related to radiation exposure.

(6) Prompt clean up and remediation exercises should be carried out where spillage has occurred.

\section{References}

Abali, B. K. (2009). Oil and Gas Exploration: What ONELGA suffers. Port Harcourt, B'Alive publications co.

Agbalagba, O. E., \& Meindinyo, R. K. (2010). Radiological impact of oil spilled environment: A Case study of the Eriemu well 13 and 19 oil spillage in Ughelli region of delta state, Nigeria. Indian Journal of Science and Technology, 3(9), 1001-1005.

Arogunjo, A. M., Farai, I. P., \& Fuwape, I. A. (2004). Impact of oil and gas industry to the natural radioactivity distribution in the delta region of Nigeria. Nigerian Journal Physics, 16, 131-136.

Avwiri, G. O., Chad-Umoren, Y. E., Enyinna, P. I., \& Agbalagba, E. O. (2009). Occupational Radiation Profile of Oil and Gas Facilities During Production and Off Production Periods in Ughelli, Nigeria. Journal Facta Universitatis:Working and Living Environmental Protection, 6(1), 11-19. 
Avwiri, G. O., Enyinna, P. I., \& Agbalagba, E. O. (2007). Terrestrial Radiation around oil and gas facilities in Ughelli, Nigeria. Journal of Applied Sciences, 7, 1543-1546. http://dx.doi.org/10.3923/jas.2007.1543.1546

Avwiri, G. O., \& Ebeniro, J. O. (1998). External environmental radiation in an industrial area of rivers state. Nigerian Journal of Physics, 10, 105-107.

Briggs-Kamara, M. A., Sigalo, F. B., Chad-Umoren, Y. E., \& Kamgba, F. A. (2009). Terrestrial Radiation Profile of a Nigerian University Campus: Impact of Computer and Photocopier Operations. Journal Facta Universitatis: Working and Living Environmental Protection, 6(1), 1-9.

Chad-Umoren, Y. E. (2012). Ionizing Radiation Profile of the Hydrocarbon Belt of Nigeria. In Mitsuru Nenoi (Ed.), Current Topics in Ionizing Radiation Research, InTech Publications, Janeza Trdine 9, 51000 Rijeka, Croatia.

Chad-Umoren, Y. E., Adekanmbi, M., \& Harry, S. O. (2006). Evaluation of Indoor Background Ionizing Radiation Profile of a Physics Laboratory. Journal Facta Universitatis: Working and Living Environmental Protection., 3(1), 1-8.

Chad-Umoren, Y. E., \& Obinoma, O. (2007). Determination of Ionizing Radiation Level of the Main Campus of the College of Education, Rumuolumeni, Rivers State, Nigeria. Int'l Journal of Environmental Issues, 5(1\&2), 5-10.

Chad-Umoren, Y. E., \& Briggs-Kamara, M. A. (2010). Environmental Ionizing Radiation Distribution in Rivers State, Nigeria. Journal of Environmental Engineering and Landscape Management, 18(2), 154-161. http://dx.doi.org/10.3846/jeelm.2010.18

Chukwuocha, E., \& Enyinna, P. I. (2009). Radiation monitoring of facilities in some oil wells in Bayelsa and Rivers states. Scientia Africana, 9(1), 98-102.

Ebong, I. D. U., \& Alagoa, K. D. (1992). Estimates of gamma-ray background air exposure at a fertilizer plant. Discovery and Innovation, 4, 25-28.

ICRP. (1990). Recommendations of International Commission of Radiological Protection. Oxford: Pergamon press.

Meindinyo, R. K., \& Agbalagba, O. E. (2012). Radioactivity concentration and heavy metal assessment of soil and water, in and around Imirigin oil field, Bayelsa state, Nigeria. Journal of environmental chemistry and Ecotoxicology, 42, 29-34.

OGP. (2008). Guidelines for the management of Naturally Occurring Radioactive Material (NORM) in the oil \& gas industry, International Association of Oil \& Gas Producers.

Oluwole, A. F., Olaniyi, H. B., Akeredolu, F. A., Ogunsola, O. J., \& Obioh, I. B. (1996). Impact of the Petroleum Industry on Air Quality in Nigeria, Presented at the 8th Biennial International Seminar on the Petroleum Industry and the Nigerian Environment, Port Harcourt, 17-21 November, 1996.

Ononugbo, C. P., Avwiri, G. O., \& Chad-Umoren, Y. E. (2011). Impact of Gas Exploitation on the Environmental Radioactivity of Ogba/Egbema/Ndoni Area, Nigeria. Energy and Environment, 22(8), 1017-1028. http://dx.doi.org/10.1260/0958-305X.22.8.1017

Sigalo, F. B., \& Briggs-Kamara, M. A. (2004). Estimate of Ionizing Radiation Levels within Selected Riverine Communities of the Niger Delta. Journal of Nigerian Envirironmental Society, 2, 159-162.

Stanislav, P., \& Elena, C. (1998). Environmental Impact of the Off-shore Oil and Gas Industries. East Northport, USA.

United Nations Development Programme (UNDP). (2006). Niger Delta Human Development report: Environmental and Social Challenges in the Niger Delta. UN House, Abuja, Nigeria.

\section{Copyrights}

Copyright for this article is retained by the author(s), with first publication rights granted to the journal.

This is an open-access article distributed under the terms and conditions of the Creative Commons Attribution license (http://creativecommons.org/licenses/by/3.0/). 